\title{
Reimški evangelij - jezik glagolskega dela
}

\author{
Andrej Perdih
}

Glagolski del Reimškega evangelija je cerkvenoslovansko besedilo hrvaške redakcije, napisano v samostanu Na Slovanech v Pragi leta 1395. V literaturi se večinoma navaja, da se $\mathrm{v}$ besedilu pojavljajo vplivi češkega jezika, pisec Reimškega evangelija pa naj bi bil po rodu Čeh, Slovak ali Hrvat. Z analizo fonetične in morfološke ravnine jezika želim preveriti, ali in v kolikšni meri lahko sprejmemo katero od teh možnosti.

Ključne besede: cerkvena slovanščina, Reimški evangelij, Texte du sacre, glagolica, hrvaška redakcija

\section{The Reims gospel: The language of the Glagolitic portion}

The Glagolitic part of the Reims Gospel is a Church Slavic text in Croatian recension written at the Emmaus monastery (known as $\mathrm{Na}$ Slovanech 'at the Slavs') in Prague in 1395. The literature often states that the text shows Czech influences and that the writer of the Reims Gospel must have been a Czech, Slovak, or Croat by birth. This analysis of the phonetic and morphological features of the language seeks to determine the extent to which any of these hypotheses can be supported.

Key words: Church Slavic, Reims Gospel, Texte du sacre, Glagolitic, Croatian recension

\section{$0 \quad$ Uvod}

Reimški evangelij, imenovan tudi Texte du sacre, je cerkvenoslovansko besedilo, sestavljeno iz dveh različnih delov. Rokopis obsega 49 listov, od tega sta dva prazna. Prvi del predstavlja 16 listov, napisanih v cirilici v jeziku ruske redakcije, drugi del pa 31 listov v glagolici v jeziku hrvaške redakcije; oba dela sta zapisana v dveh stolpcih. Izvirnik je shranjen v mestni knjižnici v Reimsu ${ }^{1}$ v Franciji pod signaturo Ms. 255.

$\mathrm{V}$ članku obravnavam tiste fonetične in morfološke prvine glagolskega dela Reimškega evangelija, ki lahko potrdijo vpliv češkega jezika na besedilo in iz katerih se lahko sklepa na izvor pisca. ${ }^{2}$

1 Bibliothèque municipale de Reims.

2 To temo sem obširneje obravnaval v svojem diplomskem delu pod mentorstvom doc. dr. Vande Babič (Jezik glagolskega dela Reimškega evangelija: diplomsko delo, Ljubljana, 2007). 
Glagolski del je fragment misala, zapisan v oglati glagolici. Obsega 31 listov (62 strani) in je zapisan s po 20 vrsticami na stran. Sedemnajst inicial na začetkih evangelijev je zanimivih zato, ker to niso glagolske črke, temveč latinske, predvsem gre za $V \mathrm{v}$ zvezi $V$ ono vreme. To je značilnost hrvaških rokopisov in tiskov, npr. reške in senjske tiskarne (Bakmaz 1981: 122-127). V češkem glagolskem pripisu na koncu evangelija je kot leto zapisa navedena letnica 1395, kot kraj pa Emavški samostan. Tega je leta 1347 ustanovil Karel IV., češki kralj in nemški cesar.

Na splošno se sprejema, da je glagolski del Reimškega evangelija zapisan $\mathrm{v}$ hrvaški redakciji cerkvene slovanščine z nekaterimi bohemizmi. Zapisal naj bi ga bodisi Čeh (Kowalenko 1961: 467; Režić 1983: 139-140) bodisi Slovak (tako Kopitar v svojem predgovoru k Silvestrovi izdaji Reimškega evangelija, prevod v Bernard 1995: 219). Možnost, da je besedilo napisal Hrvat, ki je (dalj časa) živel na Češkem, zagovarja Vrana (1984: 114). Kuev (1986: 16-17), Bogdanov (1990: 156-165) in mnogi drugi tega vprašanja ne obravnavajo.

Medtem ko je o jeziku cirilskega dela Reimškega evangelija napisanih veliko razprav, ${ }^{3}$ so se jezikoslovci pri glagolskem delu zadovoljili z razlago, da gre za hrvaško redakcijo s konca 14. stoletja in da se $\mathrm{v}$ besedilu pojavljajo nekateri bohemizmi - omenjajo primere, navedene v prejšnjem odstavku. Dosedanje jezikovne obravnave glagolskega dela Reimškega evangelija so redke in niso podrobne; meni dostopne so bile navedbe J. Kopitarja (Bernard 1995, 1996) in K. Režić (1983), drugi avtorji pa zgolj zapišejo do zdaj uveljavljeno mnenje, da se v besedilu pojavljajo bohemizmi, brez konkretnih navedb. O vsebini Reimškega evangelija sta z liturgičnega vidika razpravljala A. Vykoukal (1948) in K. Režić (1983).

\subsection{Objave besedila}

$\mathrm{Za}$ analizo sem uporabil dve izdaji Reimškega evangelija, in sicer prvo izdajo (Silvestre 1843), ${ }^{4}$ ki je dejansko izšla leta 1844, in izdajo V. Hanke, ki je izšla dve leti kasneje (Hanka 1846). ${ }^{5}$ V Hankovi izdaji je glagolski del prečrkovan v cirilico, spremlja pa ga prepis v latinici, kjer so vse title in druge krajšave razrešene. Prečrkovani glagolski del se v tej izdaji začne na strani 67 (latinični prepis na strani 66).

$\mathrm{V}$ pomoč pri presojanju besedila in primerjavi Reimškega evangelija $\mathrm{z}$ besedili hrvaške redakcije mi je bila moderna izdaja besedila Hrvojevega misala (Grabar 1973), napisanega v letih 1403-1404, saj vsebuje primerjavo z Roškim misalom iz

3 V zadnjem času je o jeziku cirilskega dela Reimškega evangelija v svoji doktorski disertacija pisala Elvira Bikkínina (La lengua del Evangelio de Reims, Granada - Kazan', 2009), spletni dostop: http://hera.ugr.es/tesisugr/18095537.pdf, zadnji dostop 25. 3. 2010.

4 Zahvaljujem se Antonii Bernard iz Pariza, ki mi je dobrohotno priskrbela fotokopijo Silvestrove izdaje. V Narodni in univerzitetni knjižnici (NUK) v Ljubljani so pod signaturo R III 36021 shranjene litografije Reimškega evangelija, ki so se ohranile v kot nevezani listi, ne pa Silvestrova izdaja kot taka.

5 V Sloveniji je en izvod dostopen v Knjižnici Oddelka za slovenistiko in Oddelka za slavistiko na Filozofski fakulteti v Ljubljani (signatura Text II 131), dva pa hranijo v NUK-u (signaturi 20368 in 20667). 
leta 1420, Vatikanskim misalom Illyrico 4 iz leta 1315 in Novakovim misalom iz lega $1368 ;^{6}$ ti misali so bili torej napisani v približno istem času kot glagolski del Reimškega evangelija, zato so bili ustrezni za primerjavo z njim.

\section{Dosedanja argumentacija o vprašanju izvora pisca glagolskega dela Reimškega evangelija}

Kopitar svoje mnenje, da je bil pisec Slovak, dokazuje z besedami kot npr. budjet (v Reimškem evangeliju dejansko zapisano kot budět) in podobnimi. Kot se je pokazalo tudi pri analizi rabe grafemov $\check{e}$ in $e$, te trditve danes ne moremo sprejeti. Kopitarju se zdi zabavna prevajalčeva nerodnost, ko »ohranja neznano mu latinsko besedo imbres« (Bernard 1995: 219-220). Pri tem naj omenim, da se ta beseda pojavlja tudi v HM, Nk, Ro, $\mathrm{Ill}_{4}$.

K. Režić svojo trditev, da je materni jezik prepisovalca češčina, utemeljuje z bohemizmi, ki »jih v predlogi ni bilo: umivadlnica, modlitav idr.« (Režić 1983: 140). Režićeva ne piše, katera predloga je bila uporabljena, niti v Reimškem evangeliju ni oblike **modlitav, kot navaja Režićeva, saj je vedno uporabljena ligatura $m \widetilde{l v}$.

Vrana (1984: 114) utemeljuje svojo trditev, da je bil pisec Hrvat, z uporabo črke $g$ namesto $h$ in $\mathrm{z}$ napačnim zapisom potlě namesto podle, oboje $\mathrm{v}$ češkem pripisu. Res je, da je v češkem pripisu uporabljen grafem $g$ na mestu češkega $h$, vendar je bilo to značilno tudi za obdobje češkega glagolskega pismenstva v letih 1412-1416 (Pacnerová 1996: 46), torej dve desetletji pozneje, saj se je šele po tem obdobju začel uporabljati cirilski grafem $g$ s fonetično vrednostjo češkega $h$. V drugem Vranovem primeru pa je beseda dejansko zapisana kot podlě in ne potlě, kot piše Vrana, zato na podlagi teh argumentov ne moremo sprejeti njegovega mnenja o izvoru pisca.

\section{$2 \quad$ Fonetična analiza}

Namen analize je poiskati posebnosti, ki lahko kažejo na vplive češkega jezika, na podlagi analize pa tudi sklepati o izvoru pisca. Pri tem je bilo treba pojasniti tudi nekatere pojave, značilne za hrvaška cerkvenoslovanska besedila, saj določenemu jezikovnemu pojavu težko z gotovostjo pripišemo češki izvor, če tak pojav obstaja tudi v besedilih hrvaške redakcije cerkvene slovanščine oziroma v čakavskih narečjih, ki so podlaga za glagolski del Reimškega evangelija.

Pri fonetični analizi sem se omejil na pojave, iz katerih bi bilo mogoče videti češke jezikovne vplive. Tako opisujem posebnosti oziroma odstopanja od pričakovanih fonetičnih refleksov za hrvaško redakcijo cerkvene slovanščine na koncu 14.

6 Primeri z oznakami HM, Ill, ${ }_{4}$ Nk in Ro so povzeti iz dela Missale Hervoiae ducis Spalatensis croatico glagoliticum (Grabar 1973): HM - Hrvojev misal, Ill 4 - Vatikanski misal, Nk - Novakov misal, Ro - Roški misal. 
in začetku 15. stoletja. Med posebnostmi poskušam najti tiste, ki jih lahko pripišemo češkemu vplivu, in sicer:

- neobstoj epentetičnega $l$ na morfemskem šivu,

- ohranitev soglasniških skupin $k v$ in $g v$ pred $\check{e}_{2}$ (druga palatalizacija),

- $\operatorname{razvoj} * t i,{ }^{*} k t \bar{l}$ in $* g t \overline{\bar{l}}>c$ ter $* d i>(d) z$,

- razvoj skupine *di,

- refleks grškega palatalnega $g$,'

- vokalizacija polglasnikov $*_{b},{ }^{*} b>e$,

- ohranitev skupin $* d l$ in *tl,

- preglas *'a, *'e >

- dotaknil pa sem se tudi vprašanja zapisovanja $e$-jevskih samoglasnikov in mehkih soglasnikov.

V tem prispevku prikazujem omejeno število zgledov iz Reimškega evangelija, potrebnih za ustrezno ponazoritev obravnavanega pojava. Prečrkovani so v latinico.

\subsection{Jezikovne značilnosti, ki jih ne moremo uvrstiti med bohemizme}

Najprej si oglejmo, katerih od naštetih značilnosti češkega jezika ne najdemo v Reimškem evangeliju. Navedeni primeri so (lahko) značilni za jezik hrvaške redakcije oziroma čakavska narečja.

\section{Neobstoj epentetičnega $l$ na morfemskem šivu}

V stari cerkveni slovanščini (pa tudi v vzhodnoslovanskih in južnoslovanskih jezikih razen makedonščine in bolgarščine) se epentetični $l$ pojavlja $\mathrm{v}$ refleksih naslednjih skupin *bi, *pi, *mi , *vi> вп', пп', мп', вп'. Zahodnoslovanski (tudi makedonski in bolgarski) refleks je odvisen od mesta $\mathrm{v}$ besedi. V korenskih zlogih so refleksi enaki starocerkvenoslovanskim (ви', пп', мп', ви'), zato teh primerov posebej ne navajam. Na morfemskem šivu se epentetični $l \mathrm{v}$ zahodnoslovanskih jezikih (ter makedonščini in bolgarščini) ne pojavlja (Babič 2003: 70-71).

Primeri v Reimškem evangeliju: zmle gen. sg. f., ljublju 1. sg. prez., prosilju se 1. sg. prez. < *proslav' $Q$ se, pristup $\widetilde{l}_{b}$ nom. sg. m. akt. ptcp. pf. I., postvleni nom. pl. f. pas. ptcp. pf.

Neohranitev soglasniških skupin $k v$ in $g v$ pred $\check{e}_{2}$ (druga palatalizacija)

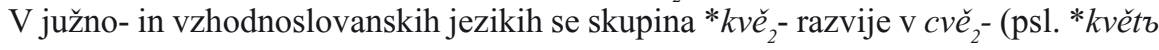

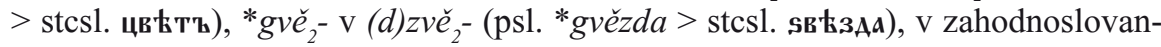
skih jezikih pa se zvezi $k v$ in $g v$ ohranjata (Babič 2003: 64-66).

Primeri v Reimškem evangeliju: cvěta, cvětb, zvězda, zvězdb, zvězdu, zvězdi.

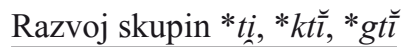

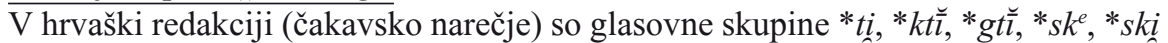

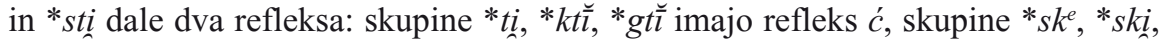
${ }^{*}$ sti pa šć. Zahodnoslovanski refleksi na tem mestu so: *ti ${ }^{*}{ }^{*} k t \overline{\bar{l}},{ }^{*} g t \overline{\bar{l}}>c,{ }^{*} s k^{e},{ }^{*} s k i$, *stị > š́c > češ., slšs. št' (Babič 2003: 64-70).

Primeri v Reimškem evangeliju: gljućimb, seděća, dećeri, noćb, svěčnci, tisući. 
$\underline{\text { Razvoj skupine } * d i}$

V glagolskem delu Reimškega evangelija se večinoma pojavlja zapis $\check{z} d$, ki je starocerkvenoslovanski refleks, redkeje pa zapis brez črke v medsamoglasniški legi oziroma zapis z znakom 'ob soglasnikih, kar predstavlja čakavski refleks $j$ (Mihaljević 1986: 130).

Primeri v Reimškem evangeliju z zapisom $\check{z} d$ - rožděniě, nužda, roždastva, prěžde, žě̌djuće.

Primeri v Reimškem evangeliju brez posebnega grafema ali z grafemom ' za [j]: narěena < *nared'en-, tvr'ěše 'okrepiti, utrditi' < *tvbrd'aaše < *tvbrd'ěaše, daite, prodaite, viite, osuen $\left(<*_{-s Q d ' e n ъ}\right)$ itd.

Refleks grškega palatalnega g' v besedah za 'angel', 'evangelij', 'vigilija'

Grški palatalni $g$ ' se je v hrv. in srb. (razen v kajkavščini) razvil tako kot psl. *di štokavsko đ (ânđeo, jevànđēlje), čakavsko $j$ (anjelskî, evanjẹlje), toda kajkavsko $g$ (angel, evangelijum). Češčina ima na tem mestu anděl, evangelium, torej d' oziroma $g$, podobno poljščina aniót, ewangelia (Babič 2000: 124).

Primeri v Reimškem evangeliju: an $\widetilde{\jmath} l b$, an $\widetilde{l} a$, an $\widetilde{\jmath} l i$, an $\widetilde{\jmath} l m b$, an $\widetilde{\jmath} l u$, eje, ej’liě, vij̄iliju.

Vokalizacija polglasnikov $*_{b}, *_{b}>e$

Nekdanja polglasnika sta se $\mathrm{v}$ šibki poziciji $\mathrm{v}$ večini primerov pričakovano izgubila, lahko pa sta (po tradiciji) v Reimškem evangeliju zapisana z znakoma $I$ ali '. Za ta prispevek so zanimivi predvsem primeri vokalizacije polglasnikov v šibki poziciji.

V Reimškem evangeliju se v položaju pred zvočniki pojavlja $a$, ki je v hrvaški redakciji nastal na dva načina:

- iz sekundarnega polglasnika, če je polglasnik za zvočnikom izpadel - osamb $<{ }^{*}$ osmb, oganb $<*$ ogn'b,

- z vokalizacijo šibkega polglasnika - dašćicu, roždastva, mazda, mazdu, maz$d i$, toda $m b z d u<* m b z d a, d v a r i<* d v b r i$.

Bolj zanimivi so primeri vokalizacije šibkih polglasnikov v $e$ v Reimškem evangeliju: dećeri, dećerb, semr'ti, semr'tnago, toda smr'ti, $\widetilde{s m r}$ 'tb. Vokalizacijo polglasnika $\mathrm{v} e$ lahko najdemo samo pri naštetih primerih in je $\mathrm{v}$ primerjavi z vokalizacijo $\mathrm{v} a$ precej redkejša. V etimološkem slovarju hrvaškega ali srbskega jezika (Skok 1972) poleg oblike smr̈t najdemo tudi čakavski obliki semrt in semart, v čakavskonemškem slovarju (Hraste idr. 1979) pa sta navedeni čakavski obliki sãmrt in smr̈t, pa tudi sicer je $e<{ }^{*},{ }^{*} b \mathrm{v}$ teh primerih čakavska značilnost.

Razvoj in zapis praslovanskih *e, *e, *

Nosnik *e se je $\mathrm{v}$ čakavščini (na kateri temelji hrvaška redakcija, pa tudi Reimški evangelij) razvil ve (greda, pet, uzeti), razen za $\check{c}, \check{z}, j$, kjer je bil razvoj $*_{e}>a$ (jazik, zajac, počat). V drugih hrvaških narečjih je tudi za temi soglasniki refleks vedno $e$. Zahodnoslovanski jeziki imajo za nekdanji $\varepsilon$ različne reflekse. V češčini je razvoj

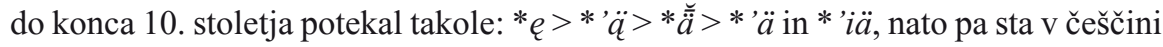
oba pred mehkimi soglasniki in $k$ prešla $\mathrm{v} \check{e}$ in se dalje razvijala kot kratki in dolgi 
- $\quad \check{e}-\operatorname{kratki} \check{e}$ za $p, b, m$ in $v>i e$, za $t, d$, in $n>$ 'e, za drugimi soglasniki $>e$ (pět < *pętb, pěkný, kotě, deset $<*$ desętb, zet'<*zętb); dolgi $\check{e}>i e>i$ (vzit $<* v b z e ̨ t i)$. Pred trdimi soglasniki sta *'ä in * 'iä prešla $\mathrm{v} * \overline{\bar{a}}($ maso $<*$ męso, pátý < *pętrjb, Babič 2003: 60).

Pri samoglasniku *ě pozna čakavščina tri vrste refleksov. Skupino ekavskih govorov (refleks $e$ ) tvorijo govori vzhodne in osrednje Istre, do 16. stoletja pa tudi govori zahodne in južne Istre. Skupino ikavsko-ekavskih govorov (refleks $e$ ali $i$, pri čemer se je $e$ lahko tudi diftongiziral) sestavljajo govori južno od Istre, in sicer na ozemlju od Reke do Senja, v Gorskem Kotarju, večini Kvarnerskih otokov in na otokih okoli zadrskega polotoka z južno mejo na Pašmanu. ${ }^{7}$ Tretja skupina so ikavski govori na otokih južno od Pašmana in na celini južno od Zadra, od 16. stoletja pa tudi v zahodni in južni Istri (Moguš 1977: 37-44). Češčina ima za *ě v dolgih zlogih refleks $i(<i e<* e$ ): víra, mřiti, símě oziroma é v položaju za $l$, npr. lék, létat, ali po metatezi *-el->*-lě-, npr. mléko. V kratkih zlogih ima češčina refleks ě (tj. ie za $p, b, m, v$ in 'e za $t, d, n)$ : pěna, květiny in tělo, dělati; za drugimi soglasniki pa $e$ po depalatalizaciji prednjega soglasnika: seno, cena. Slovaščina loči razvoj dolgega $* \check{e}>i e-$ biely, dielo - in kratkega $* \check{e}>e$, ki mehča predhodne soglasnike $t, d, n$, in l-teleso, pena, mena (Babič 2003: 54).

Samoglasnik *e ni doživel sprememb niti v čakavščini niti v češčini.

$\mathrm{V}$ hrvaški redakciji cerkvene slovanščine je črka $e$ (za zapis nekdanjih *e, $* e, * \check{e}$ ) označevala izgovor [e] za trdimi in mehkimi soglasniki oziroma izgovor [je] za samoglasnikom in na začetku besede, črka $\check{e}$ (za zapis nekdanjih * *'a) pa je označevala samoglasnik ['a] na začetku besede, za samoglasnikom in za mehkimi soglasniki $l$ ', $n$ ', $r$ ', prav tako pa je označevala refleks praslovanskega $* \check{e}$.

V Reimškem evangeliju se za označevanje $e$-jevskih glasov uporabljata črki $e$ in $\check{e}$. Njuna raba se dosledno razlikuje samo za samoglasniki, kjer e označuje izgovor [je], po izvoru bodisi *ję ali *je, ě pa označuje izgovor [ja].

\section{Raba črke $e$ :}

- Primeri rabe $e$ za izvorni *ję za samoglasniki:

končnica ak. pl. m. ì -sklanjatve: krae, ar'hierěe; končnica gen. sg. f. ia-sklanjatve: asie, brtie; končnica nom. pl. f. pridevnikov: prěvlikie, noćnie; končnica gen. sg. f. osebnega zaimka za 3. osebo *jeję - ee in něe; ak. pl. m. osebnega zaimka za 3. osebo *ję-e in ne; končnica gen. sg. f. svojilnih zaimkov, npr. *-eję-moee, tvoee, svoee; končnica nom./ak. pl. f. svojilnih zaimkov in ak. pl. m. svojilnih zaimkov na *-e pri osnovah tipa *moj-: moe, svoe, tvoe; končnica gen. sg. f. kazalnega zaimka*sb, torej oblika ${ }^{*} s e j e-s i e,{ }^{8}$ končnica ak. pl. m. istega zaimka, torej oblika *sbje - sie; gen. sg. f. zaimka *vbsb, tj. oblika *vbseje - vsee; končnica gen. sg. f. oziralnega zaimka *jaže, tj. oblika *jejęže z vzglasnim $n$ v položaju za predlogom: něeže itd.

7 Kot je znano, je večina menihov v Emavški samostan prišla ravno z otoka Pašman.

8 Oblika sie je nastala že v starocerkvenoslovanskem obdobju pod vplivom določne sklanjatve pridevnikov (Đorđić 1975: 110). 
- Primeri rabe $e$ za izvorni $*$ je za samoglasniki:

glagolske oblike s tematskim sklopom -ie- (III. sedanjiška vrsta/razred A): trěbuetb, pohulaete, umieš $i$, razuměeši sabljudaetb, povédaemi, bivaemoe, naricaemi, nbricaemi; v nom. sg. n. samostalnikov ter določnih oblik pridevnikov in deležnikov: spsenie, nьpisanie, novoe, suhomor'noe, siějućee; v instr. sg. m. in n. samostalnikov bIniemb, zmiemb; v osnovah besed: prvi $e \mathrm{v}$ ar'hierěe (drugi $e$ je nastal iz -ęv ak. pl.), v sklonskih oblikah svojilnih zaimkov moe, mоеgo, тоети itd.

- Primeri rabe $e$ za izvorni *e na začetku besede (oziroma za protetičnim $j$, tj. je-): ej’liě, egda, edinu, ego, ee, eju, edinodšno itd.

- Primeri rabe $e$ za izvorni $* e$ in * $e$ v naslednjih kategorijah:

instr. sg. io-sklanjatve mečemb, bIniemb; gen. sg. ia $a$-sklanjatve $\widetilde{z m l e}, \widetilde{d s} e ;$ ak. pl. $i a$-sklanjatve tomnice, vdovice; v končnici 2. pl. prez. pohulaete, p'ete; oblike zaimka *vbsb - vsego, vsemu; osnova se- kazalnega zaimka *sb - sego, semu; gen. sg. osebnega zaimka za 1 . osebo mene, mené; ak. sg. istega zaimka *mę >me; za 2. osebo gen. sg. tebě; ak. sg. *tę>te; povratni zaimek se ter gen. sebě in lok. istega zaimka sebé; ak. pl. m. in f. zaimka *vbsb, tj. oblika *vbsę-vse itd.

- Primeri rabe e za izvorna *e in *e v položaju za $\check{c}, \check{s}, \check{z}, \dot{c}(\check{s} c)$ : v osnovi: věčeru, otročete, nbčetbakb, začela, v 3. sg. sg. aor. načetb, nbčetb, začet'se; v končnicah: gen. sg. f. $\widetilde{d s ̌ e, ~ g e n . ~ s g . ~ s v o j . ~ z a i m . ~ n a s ̌ e g o, ~ 3 . ~ o s . ~ p l . ~ a o r . ~ v l o z ̌ i s ̌ e, ~ v s a-~}$ diše, 3. os. sg. imperfekta: možaše, hotěaše, nom. pl. f. šad'še, ak. pl. m. samostalnikov: ključe, pri participih: vzlěěécimb itd.

- Primeri rabe $e$ za izvorni $* \check{e}$ :

*nyně: $\tilde{n n e}, *$ děl (gen. pl. od *dělo): del'.

Raba črke $\check{e}:$

- Primeri rabe ě za izvorni *ja za samoglasniki:

pri samostalnikih, zaimkih in določnih oblikah pridevnikov nom. sg. f.: drugaě,

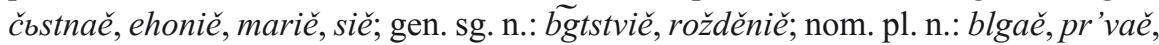
znamniě; ak. pl. n.: zmTnaě, v'voděćaé, viličiě; sredi besede něpriětelb itd.

- Primeri rabe ě za izvorni *ję za samoglasnikom: priětb, priět' itd. V teh primerih gre za čakavski refleks $a<* e \mathrm{v}$ položaju za $j$.

- Primeri rabe ě za izvorni *'a na začetku besede: éko, ěkže itd.

- Primeri rabe ě za izvorni *ě v določenih položajih, brez izjeme: predpona *prě-: prěidu, prěda, prěidětb, prěbivaju; koren *grěx-: grěhb, grěhovb, grěšnu; pri rezultatih druge palatalizacije: cvěta, cvětb, zvězda, zvězdb, zvězdu, zvěz-

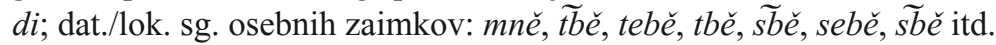

- Primer rabe ě za izvorni ${ }^{*} e$, ko pred njim ne stoji $* j$ : vzlěžećimb, věći.

- Primeri rabe ě za izvorni * $e$ :

nom. in vok. pl. $\breve{u}$-sklanjatve snvě, vok. sg. simuně in $\widetilde{h e}$.

Mešana raba $e$ in $\check{e}$ pri enakih oblikah:

$\mathrm{Za}$ zapis slovanskega ${ }^{*} e$ na začetku besede se večinoma lahko uporabljata tako $e$ kot ě. Pri besedi *język se v Reimškem evangeliju pojavljajo zapisi eziki, ezikb, ezikomb, ezikmb, pa tudi ězika, ěz $\widetilde{k m} b$, ězici, ězicehb, ěz'kb. 
- Na sredi in na koncu besede so ${ }^{*} e,{ }^{*} e$ in $* \check{e}$ (razen pri skupinah primerov, naštetih zgoraj) za soglasnikom zapisani bodisi z $e$ bodisi z $\check{e}$, in sicer:

$-* e$

v korenu besede: vět' $h i$, toda vet'se; tematski samoglasnik: pridetb, pridemb, primete, tepete, nbidetb, počnetb 'spočeti', toda prěidětb, v'čnětb, včnětb, vačněte, proženěte, živěmb; lok. sg. f. kazalnega zaimka *vbsb: vsei, toda vsěi; nom./ak. sg. $o$-sklanjatve srce, toda morě; nikalnica *ne je v veliki večini zapisana kot ně, pojavljajo pa se tudi zapisi ne.

- *e za $\check{z} d$ je navadno zapisan kot $\check{e}$ (morda je tako označena mehkost skupine $\check{z} d$ ), lahko pa tudi kot $e$ osužděni, rožděniě, nasažděnie, žděbacb, ižděnutb, toda: prěžde itd.

$-{ }^{*} e$

3. sg. prez. grědetb, velelnik grědi, toda gredetb; nom./ak. sg. n. $n$-sklanjatve *-e $>$ elě (vrmé, vrěmě, toda ime, vrme, vrěme); v korenu propetago, toda propětago, spětb $<*$ spętb itd.

$-* \check{e}$

koren glagola *věděti: vede, věmb; koren *želěz-: železnima, želězna; koren samostalnika *kolěno: koleno, kolěně; končnica lok. sg. f. trde sklanjatve nedoločnih pridevnikov morscé, livansce; lok. sg. $a$-jevskih in $o$-jevskih samostalnikov meste, početce, bozě, grobě; lok. pl. o-sklanjatve prrcehb, psalmehb, mnozěhb itd.

Kopitar za podkrepitev trditve, da je bil pisec Reimškega evangelija po izvoru Slovak, navaja, da je tematski samoglasnik pri glagolu *byti (in tvorjenkah iz tega glagola) v prihodnjiku oziroma dovršnem sedanjiku zapisan z $\check{e}$, kar naj bi kazalo na mehkost pred njim stoječega $d$ (gl. tule razdelek 1). Poglejmo si, kako so oblike tega glagola in njegove izpeljanke zapisane v 2. in 3. sg., 1. in 2. pl. (v 1. sg. in 3. pl. ni tematskega samoglasnika $e$ ):

2. sg.: budeši $(1 \times)$;

3. sg.: prěbudetb $(1 \times)$, budetb $(13 \times)$, budet' $(2 \times)$, toda sbudět'se $(1 \times)$, budětb $(10 \times)$;

1. pl.: $\widetilde{d d m b}(1 \times)$, budem $(1 \times)$;

2. pl.: budète $(3 \times)$.

Za zapis tematskega samoglasnika pri glagolu byti (in tvorjenkah iz tega glagola) je $e$ uporabljen 18-krat, $e \check{e}$ pa 14-krat. Glede na to, da zapisovanje $e$ in $\check{e}$ tudi sicer v Reimškem evangeliju ni enotno niti na mestih, kjer o mehkosti predhodnega soglasnika ne moremo govoriti, menim, da zapis z ě ne kaže zanesljivo na mehkost pred njim stoječega $d$ in da zato iz tega podatka tudi ne moremo sklepati o izvoru pisca. Za soglasniki $\check{c}, \check{s}, \check{z}, \grave{c}(\check{s} c)$, samo enkrat tudi za $\check{z} d$, je v Reimškem evangeliju vedno zapisan $e$. V preostalih primerih je zapisovanje z $e$ oziroma $\check{e}$ enotno in dosledno izpeljano samo za samoglasnikom (z upoštevanjem čakavskega ali češkega razvoja $* j e>j a)-\check{e}$ označuje izgovor [ja], $e$ pa [je]. Na začetku besede je bil pisec nedosleden samo pri oblikah besede *jezykb, sicer pa se je držal pravila, da se [je] zapisuje kot $e$, [ja] pa kot é. Za soglasniki je enotno zapisoval predpono *prě- kot prě-, nekatere končnice (ak. sg. osebnih zaimkov *mę/tę/sę vedno kot me, te in povratnega zaimka se) in nekatere korene besed (*grěx-, *květ-, *gvězd-). V številnih 
drugih primerih pa ni enotnosti v zapisovanju črk $e$ in $\check{e}$, kar pomeni, da sta se ti dve črki za soglasniki najverjetneje izgovarjali enako, tj. kot [e].

Primera za ikavski razvoj jata $(* \check{e}>i)$ v Reimškem evangeliju ni.

\subsection{Jezikovne značilnosti, ki jih lahko uvrstimo med bohemizme}

$\mathrm{V}$ prejšnjem razdelku so bili navedeni primeri iz Reimškega evangelija, ki ne izkazujejo čeških jezikovnih vplivov, tukaj pa bodo predstavljeni primeri, ki jih.

\section{$\underline{\text { Ohranitev skupin } * d l \text { in } * t l}$}

$\mathrm{V}$ besedilu sem našel en primer $\mathrm{z}$ ohranjeno skupino $d l$, in sicer umivadlnicu. To obliko navaja tudi K. Režić (1983: 140), ki obenem trdi, da te oblike v predlogi ni bilo (čeprav ne navaja, katera predloga bi to bila), nasprotno pa je oblika modlitav, ki jo Režićeva navaja, dejansko zapisana kot $m \widetilde{l v} a$ (tj. molitva) z ligaturo $m \widetilde{l}$, enako tudi pm $\widetilde{i t}{ }^{\prime} s e, m \widetilde{l v} e \check{,}, m l v u, m \widetilde{l v} u$, mlit se, mli. Jasna primera za južnoslovanski razvoj sta v besedilu dva. To sta obliki vselihb se in vseli se, nastali iz korena *-sedl- (prim. npr. Snoj 1997: 560). Nejasna je samo oblika gr'ličića, ki pa v nobenem primeru ne potrjuje zahodnoslovanskega refleksa. ${ }^{9}$

\section{$\underline{\text { Preglas *'a }>\check{e}}$}

To je pojav v razvoju češkega jezika, s katerim se označuje prehod praslovanskega *' $a$ in $(* ' \ddot{a}<) * e$ v $\check{e}$ med dvema mehkima soglasnikoma oziroma za mehkim soglasnikom in hkrati pred $k$ oziroma na koncu besede za mehkim soglasnikom. Ta pojav je značilen za večino čeških narečij (v ožjem smislu) in za severozahodni del srednjemoravskih narečij (duše, kuře, p'et). Na drugih delih srednjemoravske pokrajine do spremembe *' $a>\check{e}$ ni prišlo v kratkih končnih zlogih (tam poznajo npr. obliko nom. sg. naša kaša namesto knjižno češko naše kaše ipd.), medtem ko je razvoj *e $\left(>*^{*} \ddot{a}\right)>\check{e}$ potekal tudi na tem področju (pjet, pamnjet'). V vzhodnomoravskih in šlezijskomoravskih narečjih razvoja *'a> ě ne poznajo, *'ä $(<* e)$ pa prehaja $\mathrm{v} \check{e}$ povsod razen na koncu besede (primeri iz valaškega narečja: $m$ 'ekký, p'ekný, pam 'et', v'ec, p'et, těšký, toda hřýb'a, kuřa, t'a, sa, hled'a). V dolgih zlogih je preglas v srednje- in vzhodnomoravskih narečjih izveden (Lamprecht idr. 1986: 63-67).

V Reimškem evangeliju sem našel en primer, ki bi lahko kazal na preglas *'a

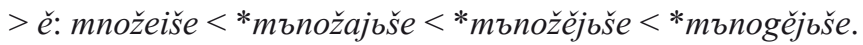

Oblika množeiše je nedoločna oblika nom. pl. m. in je komparativ pridevnika *mъnogъ. Stcsl. osnova komparativa tega primernika je мъможаиш-, npr. nom. sg. m. мъможаи, $a$ je lahko v položaju za $\check{z}$ v cerkveni slovanščini zapisan tudi kot $\check{e}$, npr. мъможћише (Kurz idr. 1958-1997: 243-244), prim. tudi Vranovo branje velelnikov na -ěte (Vrana 1975: 72). V Reimškem evangeliju kombinacija žě ne obstaja

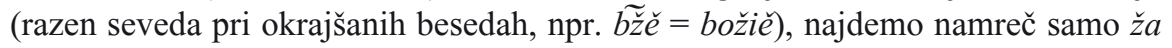
[ža] ali že [že], zato tukaj ni dvoma o fonetični vrednosti oblike množeiše. Dejansko je v stari češčini obstajala oblika nom. sg. m. množěji (Gebauer 1916: 387),

9 Z etimološkega vidika ni povsem jasno, ali je $l$ nastal iz $* l$ ali $* d l$ (ESJS: 208), vendar za našo analizo to ni relevantno. 
- $\quad$ kar potrjuje, da je oblika lahko bohemizem. Hrvaška redakcija na tem mestu ne bi imela preglasa *' $a>\check{e}$, lahko pa bi bil na tem mestu zapis z $\check{e}$ (Kurz idr. 1958-1997: 243-244; Vrana 1975: 40-41). Besedila $\mathrm{Ill}_{4}$, Hm, Ro in Nk imajo na tem mestu obliko mnozi.

\section{$3 \quad$ Pregled morfoloških posebnosti}

Večina oblik in tudi same kategorije so pričakovane za hrvaško redakcijo cerkvene slovanščine s konca 14. stoletja, zato naj navedem le dve posebnosti, ki odstopata od pričakovanj. Prva potrjuje zahodnoslovanski vpliv, druga pa tega ne potrjuje dovolj zanesljivo.

Osebni zaimek za 3. osebo ednine

Zanimiva pri osebnih zaimkih za ženski spol je oblika lok. sg. ni (v besedilu se pojavi enkrat) poleg pričakovane oblike něi (prav tako ena pojavitev). Oblika ni je nastala iz *n'eji po kontrakciji in jo lahko razlagamo kot staročeško prvino; oblika ní za predlogi je namreč obstajala že v pračeščini (Lamprecht idr. 1986: 183-184). ${ }^{10}$

Velelnik

V stcsl. se je tvoril iz sedanjiške osnove, na katero so se pritikale končnice:

\begin{tabular}{|c|c|c|c|}
\hline & I. in II. vrsta & III.* in IV. vrsta & Atematski** + *vidět $i$ \\
\hline 2. sg. & $-\mathbf{n}$ & $-и$ & $-{ }^{\prime}$ \\
\hline 3. sg. & $-и$ & $-и$ & -'b \\
\hline 1. du. & -tвk & -uвt & -ив' \\
\hline 2. du. & -kTa & -ита & -ита \\
\hline 1. pl. & $-\mathrm{t} M \mathbf{h}$ & -имъ & $-и м \mathbf{~}$ \\
\hline 2. pl. & -kTE & -ИТЕ & -ИTЕ \\
\hline
\end{tabular}

* $\quad$ Pri III. sedanjiški vrsti v vsej velelniški paradigmi prihaja do jotacije.

** Atematski glagol * byti tvori velelnik iz osnove dovršnega sedanjika *bod- po I. vrsti.

Pri tvorbi oblik velelnika se sodobna slovaščina razlikuje od sodobne češčine. V slovaškem jeziku je v velelniku prišlo do posplošitve razmerja *-i- (v ednini) : *-i(v množini) iz III. oziroma IV. vrste na vse glagole, nasprotno pa je v češkem jeziku prišlo do posplošitve razmerja *-i- (v ednini) : *-ě- (v množini) iz I. in II. sedanjiške vrste na vse glagole (Babič 2003: 179). Belić piše, da je ta pojav značilen tako za češki jezik kot tudi za nekatere stare štokavske govore in kajkavsko narečje (Belić 1962: 65). To zelo splošno razlago je treba dopolniti z Lamprechtovimi staročeškimi spregatvenimi tipi (glagole deli na 5 tipov), kjer navaja naslednje velelnike (Lamprecht idr. 1986: 202, 209-213):

10 Pračeščina se časovno uvršča v obdobje med koncem 10. in sredino 12. stoletja (Lamprecht 1986: 22). 
I. češki tip (ustreza I. stcsl. vrsti) - glagol vedu, vésti:

1. pl. veděm, -me, -my

2. pl. ved'te (jdète)

1. du. ved'vě, -va (jděvě)

2. du. ved'ta (jděta)

II. češki tip (ustreza II. stcsl. vrsti) - glagol tisknu, tisknúti:

1. pl. tiskněm, -me, -my (miňme)

2. pl. tiskněte (miňte)

1. du. tiskněvě, -va (miňvě)

2. du. tiskněta (miňta)

III. češki tip (ustreza III. stcsl. vrsti) - glagol kryju, krýti:

1. pl. krýme, -my, kryjme (kupujme)

2. pl. krýte, kryjte (kupujte)

1. du. krývě, -va (kupujvě, -va)

2. du. krýta (kupujta)

IV. češki tip (ustreza IV. stcsl. vrsti) - glagol prošu, prositi:

1. pl. prosim, -me, -my, prosme, -my

2. pl. prosite, proste

1. du. prosivě, -va, prosvě, -va

2. du. prosita, prosta

V. češki tip (izvorno III. stcsl. vrsta) - glagol dělaju, dělati:

1. pl. dělajme, -my

2. pl. dělajte

1. du. délajvě, -va

2. du. dělajta

Naj povzamem. V I. češkem tipu imajo nekateri podtipi v množini samoglasnik ě, pri drugih pa je ta samoglasnik že v tistem času izpuščen. V II. češkem tipu imajo glagoli, pri katerih se osnova konča na dva soglasnika, v pluralu samoglasnik $\check{e}$, glagoli, pri katerih se osnova konča na en soglasnik, pa tega samoglasnika nimajo. V III. češkem tipu se izvorni -ji reducira $\mathrm{v}-j \mathrm{v} 2$. osebi ednine, kar se je preneslo tudi $\mathrm{v}$ druge oblike (to je splošnoslovanska značilnost, prim. Babič 2003: 179), pri glagolih tipa kryju, krýti in b'u, biti pa je prišlo do kontrakcije (oblike $\mathrm{z}$ dolgim predhodnim samoglasnikom $y$ ali $i$ ), vendar oblike z -yj- kažejo, da je ta fonetična sprememba s časom izginila analogno po drugih velelniških oblikah (Lamprecht idr. 1986: 220-221, 236-237). Glagoli $I V$. češkega tipa imajo ali samoglasnik - $i$ - ali pa je ta samoglasnik izpadel. V $V$. češkem tipu se tako kot pri III. tipu izvorni -ji reducira $\mathrm{v}-j$.

K oblikam 2. pl. glagolov IV. vrste je treba dodati, da sodobna češčina v velelniku (tudi za glagole IV. vrste) pozna oblike na -ětel-ete (spěte $\leftarrow$ spát, myslete) in -te (proste). Že v 14. stoletju so bile oblike $\mathrm{z}-i$ - v pluralu redkejše od tistih brez $-i$-, vendar se pojavljajo tudi v čeških besedilih 14.-15. stoletja (Dostál 1967: 32-33). 
Do druge polovice 14. stoletja je bil v čakavskih besedilih običajen zapis v velelniku -ě- (požrêmb, idête, toda pri glagolu otvoriti-otvorête), nato pa se je uveljavil zapis - $i$ - tudi tam, kjer je bil nekdaj ě (požrimo, idite, otvorite, pa tudi nekdaj budête, pomenête, rbcête, pozneje budite, pomenite, rbcite) (Hamm 1963: 55).

Primeri velelnika v Reimškem evangeliju:

\begin{tabular}{|c|c|c|}
\hline \multirow[t]{3}{*}{ I. vrsta } & sg. & oblěci se, prěbudi \\
\hline & pl. & $\begin{array}{l}\text { rcěte, naiděte in } \\
\text { nemozete, prěidemb in } \\
\text { primite, otvr'zite }\end{array}$ \\
\hline & du. & $\begin{array}{l}\text { iděta, rcěta in } \\
\text { rceta in } \\
\text { privědita }\end{array}$ \\
\hline \multirow[t]{2}{*}{ III. vrsta } & sg. & naslědui, radui se \\
\hline & pl. & mudrstvuite, uzrite \\
\hline \multirow[t]{3}{*}{ IV. vrsta } & sg. & vstupi, boi se \\
\hline & pl. & $\begin{array}{l}\text { tvorete, slišete, š̃ste in } \\
\text { istreběte in } \\
\text { boite se, vněmlite }\end{array}$ \\
\hline & $d u$. & boitase \\
\hline \multirow{2}{*}{$\begin{array}{l}\text { atematski } \\
\text { in *viděti }\end{array}$} & sg. & $v i z ̌ d b$ \\
\hline & pl. & édite, vidite \\
\hline
\end{tabular}

Posebnosti:

- I. vrsta

Oblike privědita, primite in otvr'zite imajo v dvojini in množini samoglasnik -i-, ki je prevzet iz IV. vrste, enako tudi oblika atematskega glagola *byti: budite, ki tvori oblike velelnika po I. vrsti. Poleg teh oblik se v tej skupini pojavljajo tudi oblike s pričakovanim -е̌-: iděta, rcěta, rcěte.

- IV. vrsta

Poleg pričakovanih oblik věselite se, něrodite se so zapisane tudi nepričakovane tvorete ( $\mathrm{Ill}_{4}$ ima na tem mestu obliko tvorěte), istreběte (enako $\mathrm{Ill}_{4}$ istreběte), slišete (Ill ${ }_{4}$ ima na tem mestu slišěte), morda tudi s šste; spomeniki Hm, Ro in imajo na teh mestih oblike z samoglasnikom - $i$-. V Reimškem evangeliju sta tudi v dvojini in množini možni tako izvorni končnici 2. du. *-ita, 2. pl. *-ite kot tudi končnici, ki sta prodrli iz I. in II. vrste (2. du. *-ěta, 2. pl. *-ěte), zapisani z e ali ě. V rokopisu $\mathrm{Ill}_{4}$ se pri oblikah velelnika skloněte, veselěte se, hvalěte, tvorěte in pri sklonskih oblikah $o$ otročetě, materě črka ě rabi za psl. *i kot posledica ikavizma (Vajs 1948: 84). Njegovo razlago je zavrnil J. Vrana (Vrana 1975: 40-41), ker naj bi se v tem primeru 
ikavski refleks pojavil samo v teh primerih. ${ }^{11}$ Vrana oblike 2. pl. velelnika -ěte pri glagolih IV. vrste razlaga kot analogijo po I. in II. vrsti, vendar pa naj ta ne bi zajela atematskih glagolov: dadite (toda vzdaděte), édite, vědite, povédite, vidite, vižd'te ... Trdi še, da se enako (s črko ě) pišejo oblike številnih primerov 2. pl. velelnikov v starohrvaških duhovnih pesmih ${ }^{12}$ iz prve polovice 14 . stoletja - da je to analoška oblika, sklepa tudi iz primera kašn'ěte, ki ga bere [kašn'ate] tako kot analoške oblike glagolěte [glagol'ate], pokažěte [pokažate], plačate itd.; tudi v nadaljnjem razvoju čakavskih dialektov, tj. na začetku 14. st., ko so se začeli pojavljati ikavizmi, so bile tudi te velelniške oblike ikavizirane po pravilu o zamenjavi samoglasnika $e$, vendar v čakavskih spomenikih o tem ni sledu, meni J. Vrana.

- atematski glagoli in *viděti:

2. pl. glagola * viděti ima enkrat zapisano obliko vidite, dvakrat pa viite. Prva oblika ustreza obliki stcsl. видитє brez jotacije, druga pa izkazuje čakavski refleks $-j-<$ *-d'-. Glagol *(pro)dati ima oblike 2. pl. prodaite, daite. Tudi tu je množinska oblika tvorjena analogno po edninski obliki za 2 . osebo čak. $d a j<* d a d$ 'b po jotaciji $-j-<*-d$ '-. Po edninski obliki je množina pri tem glagolu narejena tako v južnoslovanskih kot zahodnoslovanskih jezikih (sln. dajte, hrv. dajte, češ. dejte).

Obe posebnosti velelniških oblik (mešanje množinskih končnic I. vrste na eni strani in IV. vrste na drugi strani ter obliko $d a j<* d a d$ 'b) znotraj sistema jezika hrvaške redakcije razlaga Vrana z navedbami iz spomenika $\mathrm{Ill}_{4}$ in starohrvaških duhovnih pesmi (Vrana 1975: 40-41).

Iz vsega navedenega je jasno, da iz velelniških oblik ni mogoče potrditi vpliva češkega jezika na nepričakovane oblike, ki so prav lahko posledica čakavskega oziroma hrvaškega cerkvenoslovanskega mešanja teh oblik.

\section{$4 \quad$ Sklep}

Analiza je pokazala, da se v glagolskem delu Reimškega evangelija pojavijo zgolj trije bohemizmi, tj. precej manj, kot dobimo vtis $\mathrm{v}$ literaturi, kjer se navadno zgolja povzema od starejših virov. Izmed fonetičnih posebnosti lahko med bohemizme štejemo v enem primeru ohranitev skupine $d l$ (umivadlnicu), v enem primeru češki preglas *' $a>\check{e}$, v zapisu kot $e$ (množeiše); izmed morfoloških posebnosti pa $\mathrm{v}$ enem primeru obliko osebnega zaimka za 3. sg. lok. f. $n i<*_{n}{ }^{\prime} e j i$. Preglas *' $a>\check{e}$ je edini pojav, iz katerega lahko sklepamo na to, da je na pisca vplivala češčina, ne pa kateri drugi zahodnoslovanski jezik. Razen teh treh bohemizmov je vse ostalo besedilo zapisano v jeziku hrvaške redakcije tistega časa. Sodeč po izraziti podobnosti glagolskega dela Reimškega evangelija predvsem

${ }^{11}$ Ta Vranova trditev ni povsem pravilna, saj Vajs navaja še primere: 0 otročetě, materě (gl. zgoraj).

${ }^{12}$ Kot vir navaja delo J. Vajsa Starohrvatske duhovne pjesme, Starine 31, Zagreb, 1898, $258-275$. 
- $\mathrm{s} \mathrm{Ill}_{4}$, pa tudi s Hm, Rk, No, moramo besedilo jezikovno uvrstiti v hrvaško redakcijo. Iz jezikovnih posebnosti Reimškega evangelija ne moremo zanesljivo sklepati, ali je bil pisec po rodu Čeh ali Čakavec, ki je živel na Češkem in zato sam v besedilo vnesel značilnosti češkega jezika.

\section{Viri in literatura}

Babič 2000 = Vanda Babič, Vpliv vzhodne cerkvene slovanščine na hrvaške glagolske tekste $v$ 17. in 18. stoletju, Ljubljana: Znanstveni inštitut Filozofske fakultete, 2000.

Babič 2003 = Vanda Babič, Učbenik stare cerkvene slovanščine, Ljubljana: Znanstveni inštitut Filozofske fakultete, 2003.

Bakmaz 1981 = Ivan Bakmaz, Prvo razdoblje hrvatskoglagoljskog tiskarstva: analiza grafije, Slovo (Zagreb) 31 (1981), 103-132.

Belić 1962 = Александар Белић, Историја српскохрватског језика II/2: речи са конјугаиијом, Београд: Научна књига, 1962.

Bernard 1995 = Antonia Bernard, Jernej Kopitar: Reimški evangelij: zgodovinski predgovor, Slavistična revija 43 (1995), št. 2, 201-222.

Bernard 1996 = Antonia Bernard, Jernej Kopitar in Reimški evangelij, v: Kopitarjev zbornik: mednarodni simpozij v Ljubljani, 29. junij do 1. julij 1994: simpozij ob stopetdesetletnici njegove smrti $=$ Obdobja 15, Ljubljana: Filozofska fakulteta, 1996, 285-292.

Bogdanov 1990 = Иван Богданов, Реймско евангелие, Литературна мисъл (София) 34 (1990), 156-165.

Dostál 1967 = Antonín Dostál, Historická mluvnice česká II: Tvarosloví 2: časování, Praha: Státní pedagogické nakladatelství, 1967, 32-33.

Đorđić 1975 = Петар Ђорђић, Старословенски језик, Београд: Матица српска, 1975.

ESJS = Helena Kupcová idr., Etymologický slovník jazyka staroslověnského, Praha: Akademie věd České republiky, Ústav pro jazyk český, 1989-2008.

Gebauer 1916 = Jan Gebauer, Slovník staročeský 2: $K-N$, Praha: Česká Akademie císaře Františka Josefa pro vědy, slovesnost a umění, 1916.

Grabar 1973 = Biserka Grabar, Missale Hervoiae ducis Spalatensis croatico glagoliticum, Zagreb: Staroslavenski institut »Svetozar Ritig« - Ljubljana: Mladinska knjiga - Graz: Akademische Druck- u. Verlagsanstalt, 1973.

Hanka 1846 = Váceslav Hanka, Сазаво-Эммаусское Святое Благовествование, ныне же Реймсское = Sazavo emmauzskoje svjatoje blagověstvovanije, nyněže Remeskoje, Въ чешьской Празъ: Печать и бумага ц. к. придворной книгопечатни сыновь Богумила Гаазе, 1846.

Hraste idr. 1979 = Mate Hraste idr., Čakavisch-deutsches Lexikon 1, Köln - Wien: Böhlau, 1979. 
Kowalenko 1961-1996 = Władysław Kowalenko, Stownik starożytności stowiańskich, encyklopedyczny zarys kultury Stowian od czasów najdawniejszych, Wrocław idr.: Zakład narodowy im. Ossolińskich, Wydawnictwo Polskiej akademie nauk, 1961-1996.

Kuev 1986 = Кујо Куев, Съдбата на старобългарската ръкописна книга през вековете, София: Наука и изкуство, ${ }^{2} 1986$.

Kurz idr. 1958-1997 = Josef Kurz idr., Slovník jazyka staroslověnského $=$ Lexicon linguae palaeoslovenicae, Praha: Academia, 1958-1997.

Lamprecht idr. 1986 = Arnošt Lamprecht idr., Historická mluvnice češtiny, Praha: Státní pedagogické nakladatelství, 1986.

Moguš 1977 = Milan Moguš, Čakavsko narječje: fonologija, Zagreb: Školska knjiga, 1977.

Pacnerová 1996 = Ludmila Pacnerová, Česká varianta charvátské hranaté hlaholice, Slovo (Zagreb) 44-46 (1996), 45-62.

Režić 1986 = Ksenija Režić, Remsko evanđelje prema hrvatskoglagoljskom lekcionaru, Croatica (Zagreb) 19 (1986), 137-153.

Silvestre 1843 = Joseph Balthasar Silvestre, Evangelia slavice, quibus olim in Regum Francorum oleo sacro inungedorum solemnibus uti solebat ecclesia Remensis vulgo Texte du Sacre ad exemplaris similitudinem descripsit et edidit Silvestre Ordinis S. Gregorii Magni unus e Praefectis aliorumque Ordinum Eques, Paris: Firmin-Didot, 1843.

Skok 1972 = Petar Skok, Etimologijski rječnik hrvatskoga ili srpskoga jezika 2: Kponi ${ }^{1}$, Zagreb: Jugoslavenska akademija znanosti i umjetnosti, 1972.

Snoj 1997 = Marko Snoj, Slovenski etimološki slovar, Ljubljana: Mladinska knjiga, 1997.

Vrana 1975 = Josip Vrana, Najstariji hrvatski glagoljski evanđelistar, Beograd: SANU, 1975.

Vrana 1984 = Josip Vrana, O postanku ćirilskoga teksta Reimskog evanđelja, Slavia (Praha) 53 (1984), 113-123.

Vykoukal 1948 = Arnošt Vykoukal, Remešský staroslovanský Evangeliár̆, zvaný »Texte du sacre«, s liturgického hlediska, v: Slovanské studie: sbírka statí věnovaných prelátu univ. prof. dr. Josefu Vajsovi k uctění jeho životního díla, V Praze: Vyšehrad, 1948, 189-206. 


\section{The Reims Gospel: The language of the Glagolitic portion}

\section{Summary}

The Glagolitic part of the Reims Gospel is a Church Slavic text in Croatian recension written at the Emmaus monastery (known as $\mathrm{Na}$ Slovanech 'at the Slavs') in Prague in 1395. The first modern edition of the text was published in 1844 (with the publication year 1843), and the foreword was written by the Slovenian linguist Jernej Kopitar. Studies to date of the Reims Gospel generally state that the work contains many Czechisms. There may be two reasons for this: the first is the fact that it was written in Prague, and the second is the possibility that the writer was a Czech, perhaps a Slovak, although some advocate the position that the writer was a Croat. This article analyzes the phonetic and morphological features of the text, showing that only two special phonetic features can be considered Czechisms (preservation of the cluster $d l$ in the form umivadlnicu 'washbasin' and the Czech metaphony *' $a>\check{e}$ in the form množeiše 'more numerous', written as $e$ in the text), and one special morphological feature (the third-person singular locative feminine pronominal form $n i<*_{n}$ 'eji). Parallels for the other special linguistic features in the Glagolitic part of the Reims Gospel can be found in less common features of the Croatian recension of Church Slavic and in Old Croatian religious texts from this period. Because the Czechisms in the text are so infrequent, it is not possible to draw a reliable conclusion regarding the writer's origin. 